\title{
O Fundo \\ José Roberto do Amaral Lapa
}

\author{
Ana Carolina de Moura Delfim Maciel \\ amaciel@unicamp.br
}

\section{Resumo}

O texto aborda o Fundo José Roberto do Amaral Lapa, conjunto depositado no Centro de Memória Unicamp (CMU) e que reúne acervo pessoal e institucional do titular - docente do Departamento de História da Unicamp e fundador do CMU -, compreendendo correspondência ativa e passiva, diários, artigos, textos de pesquisa, artigos de jornais, fotografias etc. Além dos aspectos eminentemente profissionais, tais fontes trazem subjacentes fragmentos da história de vida do Prof. Lapa, extrapolando fronteiras institucionais. Refletir sobre as motivações que o levaram a armazenar suas próprias fontes, remete à sistematização de uma prática e permite repensar o projeto memorialístico em torno do qual o CMU se consolidou.

Palavras-chave: Fundo; José Roberto do Amaral Lapa; Memória; CMU.

\begin{abstract}
"[...] embora nos sonhos da infância e, com certeza, nos projetos dos meus pais não tivesse muito lugar para a história, eu acabei optando pela história, mas acho que havia raizes que me ajudaram, a definir essa preferência pela bistória de Campinas".
\end{abstract}

José Roberto do Amaral Lapa (In: SIMSON, 2000).

O Fundo JRAL é a base da minha pesquisa intitulada "Centro de Memória-Unicamp, gênese e manutenção projeto de um projeto memorialístico, 1985-1995”. Atualmente em fase de desenvolvimento no CMU, a pesquisa consiste numa proposta de análise da trajetória do historiador e professor do Instituto de Filosofia e Ciências Humanas (IFCH/Unicamp), José Roberto do Amaral Lapa (1929-2000), à frente do Centro. O decênio selecionado (1985-1995) compreende sua fundação e gestão inicial, período fulcral para a constituição do acervo de fontes relacionadas à história de Campinas e região, entre os séculos XVIII e XX. Os documentos integram os acervos pessoal e institucional do Prof. Lapa, compreendendo correspondência ativa e passiva, diários, artigos, textos de pesquisa, artigos de jornais, fotografias etc.

A preservação dessa documentação origina um conjunto documental que traz informações concernentes às suas práticas individuais, notadamente no que tange à concepção, planejamento e criação do $\mathrm{CMU}$, assim como os procedimentos provenientes de suas produções intelectuais/acadêmicas. É funda-

1 Pesquisadora do CMU, com mestrado e doutorado em História pela Unicamp. Fez pós-doutorado no Museu Paulista da Universidade de São Paulo e na École des Hautes Ėtudes em Sciences Sociales (Paris). Além de produção teórica textual, atua como diretora de documentários, tendo realizado vários filmes no cruzamento entre pesquisa historiográfica e realização audiovisual. 
$\mathrm{CMU}$ : arquivo e suas fontes

mental ressaltar que, além dos aspectos eminentemente profissionais, tais fontes trazem subjacentes fragmentos da história de vida do Prof. Lapa, extrapolando fronteiras institucionais. Refletir sobre as motivações que o levaram a armazenar suas próprias fontes, remete à sistematização de uma prática, devidamente dimensionada por Artières (1998, p. 28):

\begin{abstract}
Sempre arquivamos as nossas vidas em função de um futuro leitor autorizado ou não (nós mesmos, nossa família, nossos amigos ou ainda nossos colegas). Prática íntima, o arquivamento do eu tem muitas vezes uma função pública. Pois arquivar a própria vida é definitivamente uma maneira de publicar a própria vida, e escrever o livro da própria vida que sobreviverá ao tempo e à morte.
\end{abstract}

Uma análise detida da referida documentação possibilita acompanhar mecanismos intrínsecos do processo de patrimonialização documental materializado no acervo do CMU, contribuindo, portanto, para situar esse órgão como resultante de ações concretas, mas igualmente, dimensionar aspectos iminentemente subjetivos que nortearam tais ações, dentre as quais a urgência em "salvar" um legado documental em vias de desaparecimento. Afinal, como coloca Stocker (2014, p. 47), "é claro que por trás de todo arquivo há seres humanos".

Uma vez legitimado pela instituição de salvaguarda, o documento adquire aura de "patrimônio". É preciso, contudo, apresentar algumas indagações que remetem aos contextos e às forças que lançam determinado legado material ao estatuto de patrimônio. Assim, processos curatoriais trazem subjacentes problemáticas, dentre elas: porque selecionar um lote documental em detrimento de outro? Quão significativo é o acervo? É mister reiterar que o Prof. Lapa era sobretudo um historiador, com formação e interesses específicos. Sua busca por fontes primárias estava em consonância com um interesse maior, qual seja, a história de Campinas.

Instituições de memória conservam e apresentam fragmentos do passado, e seus acervos são fruto de escolhas. Um dos eixos de minha pesquisa reside em aprofundar a ação curatorial de Lapa, fornecendo subsídios para uma inteligibilidade das mediações instauradas por ele com seus doadores (e colecionadores). Pretendo contribuir também com uma análise sobre a imagem atribuída ao Prof. Lapa, em que os aspectos biográficos confluem para a materialização do acervo documental, posicionando o CMU como consequência do seu amor e dedicação à história de Campinas; de sua postura como salvador - e preservador - incansável da memória documental regional, justificando sua comparação a um garimpeiro em busca de fontes.

Algumas chaves interpretativas desse acervo restam "guardadas" em documentos e/ou na lembrança de seus contemporâneos. Considero que um recuo ao contexto inaugural possibilitará, portanto, tecer novas chaves interpretativas. Assim como a historiografia volta-se para analisar o ato de "fazer história", fontes documentais depositadas em arquivos também obedecem a critérios de escritura. Sendo assim, é importante fazer alguns questionamentos à origem desse acervo: Qual história Lapa pretendeu "escrever" com a reunião de tais documentos? Como sua produção historiográfica corroborava tal projeto de salvaguarda? Como se atrela à sua biografia uma "justificativa” pela escolha da temática regional?

Ao lançar tais prerrogativas, tenho em mente conceitos difundidos por Terry Cook (1998), que enfatiza a necessidade de analisar os processos implicados na "criação dos documentos". Pretendo refletir o binômio Lapa/CMU como proveniente de inter-relações, tendo em vista que, ainda segundo Cook (1998, p. 140), "as relações de poder que conformam a herança documental lhe dizem tanto, se não mais, que o próprio assunto que é o conteúdo do texto”. Em consonância a reflexões historiográficas voltadas à subjetividade, ao redimensionamento do estatuto do documento e ao reconhecimento da presença ativa do sujeito, Cook assim define o estatuto das fontes arquivísticas: 
Nada é neutro. Nada é imparcial. Tudo é conformado, apresentado, representado, simbolizado, significado, assinado, por aquele que fala, fotografa, escreve, ou pelo burocrata governamental, com um propósito definido, dirigido a uma determinada audiência (COOK, 1998, p. 140).

Jacques Le Goff (1996, p. 548), ao analisar o estatuto do documento, sentenciava: “Todo documento é mentira". É precisamente nessa perspectiva analítica, descortinando "condições de produção", analisando o papel do "protagonista" e do "cenário" onde se desenvolvem as ações salvaguarda documental e produção acadêmica, que minha pesquisa se desenvolve.

Habitualmente convivemos com memórias oriundas tanto do universo privado quanto do público. Há uma memória individual, que habita os meandros da subjetividade de cada um, comandada pela emoção, obedecendo a ordens internas, memória esta pautada, por vezes, em lembranças indeléveis. Concomitantemente, há uma memória "material” produzida cotidianamente pelos indivíduos, e que vai se configurando como "memória" com o transcorrer do tempo, uma memória palpável, que pode ser vislumbrada e/ou manuseada. A manutenção, preservação ou "descarte" dessa "memória material" depende de fatores externos, dentre os quais a ação do tempo e/ou a ação humana. Assim, a pesquisa contribuirá com uma perspectiva analítica que, espero, possibilitará nuançar fronteiras, entrelaçando fontes documentais, memória e historiografia.

\section{Referências}

ARTIÈRES, Philippe. Arquivar a própria vida. Revista Estudos Históricos, v. 11, n. 21, p. 9-34, 1998. Disponível em: < http://bibliotecadigital.fgv.br/ojs/index.php/reh/article/view/2061/1200>. Acesso em: 20. ago. 2015.

COOK, Terry. Arquivos Pessoais e Arquivos Institucionais: para um entendimento arquivistico comum da formação da memória em um mundo pós-moderno. Estudos Históricos, v. 11, n. 21, p. 129-149, 1998. Disponível em: <http://bibliotecadigital.fgv.br/ojs/index.php/reh/article/view/2062>. Acesso em: 20. ago. 2015.

LE GOFF, J. Documento/ Monumento. In: . História e Memória. Tradução de Bernardo Leitão et al. Campinas: Unicamp, 1996.

SIMSON, O. R. V. (Org.). O Garimpeiro dos Cantos e Antros de Campinas. Campinas: CMU/Unicamp, 2000.

\section{Dados sobre o fundo:}

Título: José Roberto do Amaral Lapa

Código de referência: BR CMU JRAL

Período de acumulação: 1929 até 2000

Procedência: Documentos doados pela família ao CMU em agosto de 2008.

Âmbito e conteúdo: Documentos relacionados a atividades privadas e públicas do titular.

Composição: Documentos textuais; bibliográficos; iconográficos; filmográficos e micrográficos. 
CMU: arquivo e suas fontes

\section{Especificações da documentação:}

- Correspondência ativa e passiva;

- Manuscritos de produções intelectuais;

- Relatórios e planejamentos;

- Documentos administrativos (atas, pautas, deliberações);

- Recortes de jornais;

- Resenhas;

- Dossiês de livros;

- Bibliografia;

- Objetos;

- Gravações orais e audiovisuais;

- Fotografias. 